\title{
CLOSTRIDIUM TERTIUM ISOLATED FROM FEED
}

Dubravka Milanov ${ }^{1^{*}}$, Milan Đilas ${ }^{2}$, Maja Velhner ${ }^{1}$, Nevenka Aleksić ${ }^{3}$

${ }^{1}$ Scientific Veterinary Institute „Novi Sad“, Novi Sad, Republic of Serbia

${ }^{2}$ Institute of Public Health of Vojvodina, Novi Sad, Republic of Serbia

${ }^{3}$ University of Belgrade, Faculty of Veterinary Medicine, Belgrade, Republic of Serbia

\section{Abstract}

Although Clostridium tertium is supposed to be a foodborne pathogen, the data on its detection in foodstuffs is scarce, and there are no reports on its isolation from feed. In this communication paper, the isolation of C.tertium from a sample of soya semolina is described. C. tertium may be important in differential diagnosis, when it is to be distinguished from Clostridium perfringens. It is a unique species due to the lack of key characteristics of the genus it belongs to because it grows in the presence of oxygen and does not produce toxins. It has been well-documented as a human pathogen, although its mechanisms of pathogenicity are still unknown. According to sporadic reports in veterinary medicine, it has been identified as a rare causative agent of infections in cattle, pigs, birds and marine mammals.

Keywords: Clostridium tertium, soya semolina, MALDI-TOF

\footnotetext{
${ }^{1 *}$ Corresponding author: dubravka@niv.ns.ac.rs
} 


\title{
IZOLACIJA CLOSTRIDIUM TERTIUM IZ HRANE ZA ŽIVOTINJE
}

\author{
Dubravka Milanov ${ }^{1}$, Milan Đilas², Maja Velhner ${ }^{1}$, Nevenka Aleksić $^{3}$ \\ ${ }^{1}$ Naučni institut za veterinarstvo „Novi Sad“, Novi Sad, Republika Srbija \\ ${ }^{2}$ Institut za javno zdravlje Vojvodine, Novi Sad, Republika Srbija \\ ${ }^{3}$ Univerzitet u Beogradu, Fakultet veterinarske medicine, Beograd, Republika Srbija
}

\section{Kratak sadržaj}

Pretpostavka je da Clostridium tertium treba svrstati u patogene koji se mogu preneti hranom, ali je malo podataka o njegovom nalazu u namirnicama, dok o izolaciji iz hrane za životinje nema dostupnih izveštaja. U ovom saopštenju prikazujemo izolaciju C. tertium iz uzorka sojinog griza. C. tertium može biti od značaja u diferencijalnoj dijagnostici kod izolacije Clostridium perfringens. Specifična je vrsta jer ne poseduje ključne karakteristike roda kojem pripada: raste u prisustvu kiseonika i ne produkuje toksine. Dobro je dokumentovan kao humani patogen, iako su mehanizmi njegove virulencije i danas nepoznati. Na osnovu sporadičnih izveštaja u veterinarskoj medicini, identifikovan je retko kao uzročnik infekcija goveda, svinja, ptica i morskih sisara.

Ključne reči: Clostridium tertium, sojin griz, MALDI TOF

\section{INTRODUCTION}

Bacterium species of the Clostridium genus are endospore-forming, obligate anaerobes (or relatively oxygen-tolerant) widespread not only in solid and liquid environments (soil, sewage, surface waters, marine sediments, etc), but also in animal and human intestines and, eventually, in animal and plant products. Based on its rRNA structure, the genus comprises extremely heterogeneous species, many of which share phylogenetic similarities with some other bacterial genera (Collins et al., 1994). Owing to its capability to produce enteritis and enterotoxaemia in various domestic animals, Clostridium perfringens is the most important clostridium species in veterinary medicine. Animal feed is one of potential sources of infection. According to regulations on the microbiological criteria for animal feed quality, it is considered safe if 
no Clostridium perfringens and Clostridium botulinum are detected in $50 \mathrm{~g}$ of a sample (Regulation on the Quality of Animal Feed, 2010). The isolation and identification of $C$. perfringens should be done in compliance with the EN ISO 7937 standard, which enables the precise identification and enumeration of the target species in food and animal feeding stuff. The identification of other members of Clostridium genus is not part of the routine procedure in laboratories for feed analysis in Serbia and is beyond their diagnostic capacity. For the above mentioned reasons, this case report is a result of an aspiration to satisfy the researchers' curiosity, discover the identity of certain Clostridium isolates from feed and to broaden the knowledge about bacterium species (other than C. perfringens) present in animal feedstuffs and feed. The isolation and identification of Clostridium tertium is presented in this communication paper. To the best of our knowledge, Clostridium tertium has not yet been detected in animal feed samples, although it is sometimes present in food of animal origin.

\section{A REPORT ON A LABORATORY CASE}

Sample: Soya semolina.

Isolation: Clostridia were isolated following the instructions given in the EN ISO 7937:2010 Standard. For further confirmation, five colonies black in colour due to sulphite reduction - grown on TSC (tryptone-sulfite-cycloserine) agar (Biokar Diagnostics, France) were chosen. They were inoculated into thioglycollate broth and incubated for 24 hours at $37^{\circ} \mathrm{C}$ (Fig 1.A). After incubation, 5 drops of thioglycollate culture was inoculated into lactose-sulfite (LS) broth (Biokar Diagnostics, France) for C. perfringens confirmation. After 24 hours of incubation at $46^{\circ} \mathrm{C}$, LS was examined for gas production and the presence of black colour (sediment of iron sulfite). The formation of black colour has been observed, but Durham's tube was filled with gas to less than a 1/4 of its volume (Figure 1.B). According to ISO standard, the test in LS medium should be repeated in this case by transferring 5 drops of culture grown in LS broth to another test tube with the same medium, repeating the incubation in the same conditions. As the repeated test once again failed to confirm the presence of Clostridium perfringens species, the culture which grew in thioglycollate medium was transferred by streaking onto two plates with Columbia blood agar base with the addition of $5 \%$ of defibrinated sheep blood. The plates were incubated at $37^{\circ} \mathrm{C}$, one in aerobic and the other in anaerobic conditions using GasPak EZ (Becton Dickinson and Company, USA). After 24 hours of incubation, the growth was noted only on the plate which was incubated in anaerobic conditions, which led to the conclusion that the species is a strict 
anaerobe. However, after 48 hours, the growth was also observed in the dish incubated in aerobic conditions, which would have led to ambiguity if it had been a Clostridium species. The isolate formed little (about $1 \mathrm{~mm}$ in diameter), opaque colonies, surrounded by a zone of incomplete (a) haemolysis (Figure 1.C). It was confirmed that it was Clostridium genus by a negative test for catalase and the microscopic appearance of the Gram stained smears: Gram-positive rods with rounded ends were found and oval spores located terminally were rarely present in smears made from cultures grown in anaerobic conditions. Based on characteristic black colonies grown on sulfite cycloserine agar, Gram-stain morphology and negative catalase test results, the isolates were presumptively identified as Clostridium species.

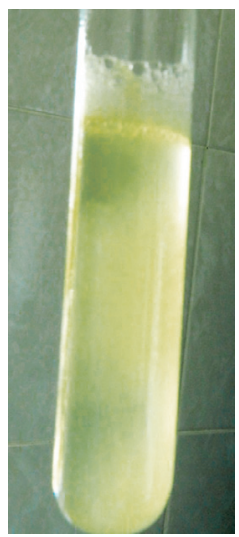

A.

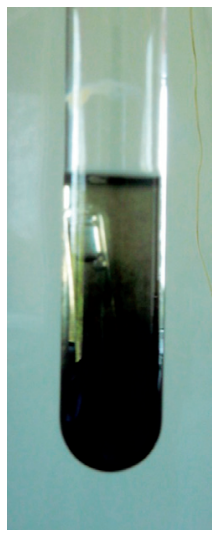

B.

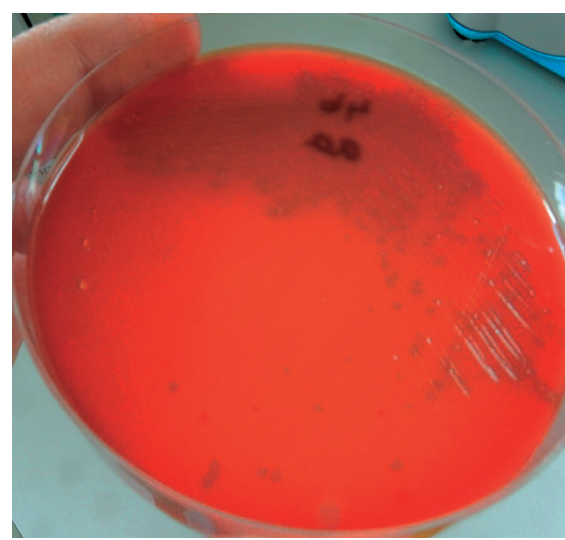

C.

Figure 1. A. Growth of the isolate in thioglycollate medium; B. Test in lactose-sulfite medium; C. Colonies of Clostridium sp. isolate on blood agar.

Due to the lack of tests for biochemical and molecular typing of isolates of Clostridium species other than C. perfringens in our laboratory, the isolate was further processed at the Institute of Public Health of Vojvodina in Novi Sad. The identification was performed with matrix-assisted laser desorption/ionization time-of-flight mass spectrometry (MALDI-TOF MS). MALDI-TOF MS has been adapted to generate protein mass spectra from whole bacteria and other microorganisms. These spectra can be compared to a reference database for rapid and accurate taxonomic classification of unknown organisms at the genus, species, and, in some cases, at strain levels. The isolate was identified by MALDI TOF as Clostridium tertium (Fig 2). 


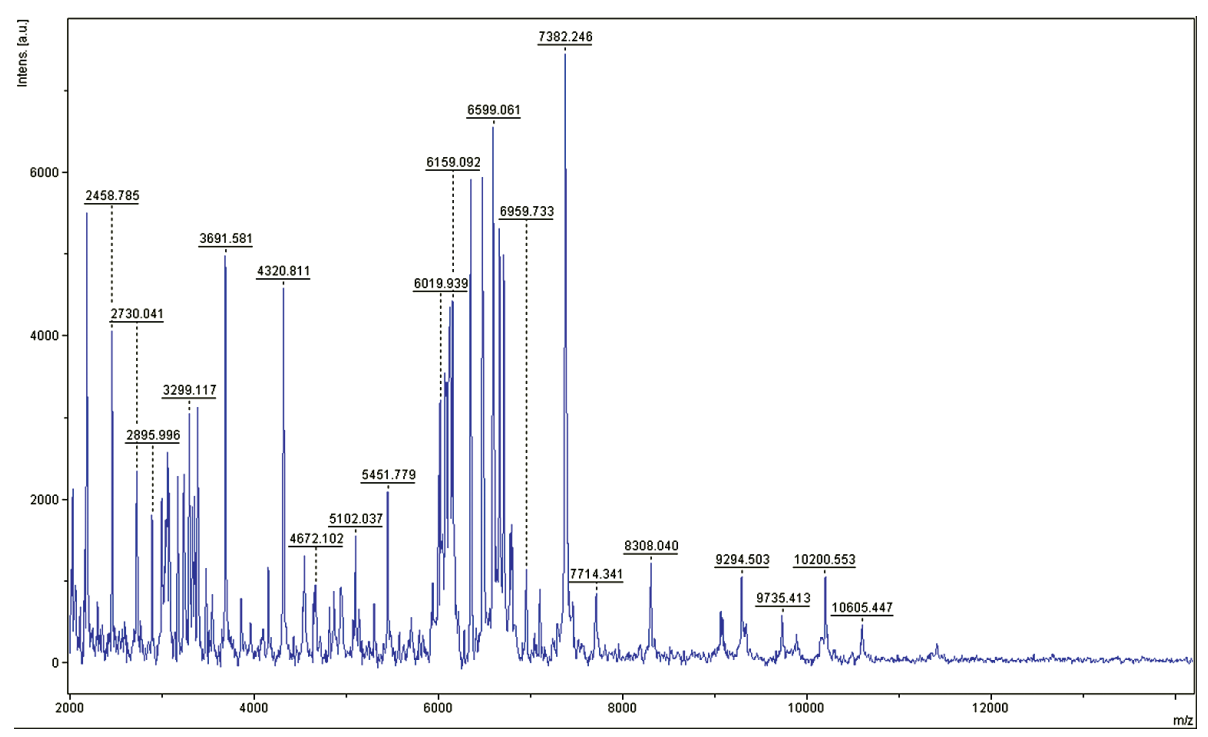

Figure 2. Spectra of Clostridium tertium isolate generated by MALDI-TOF Bruker flexControl software.

\section{COMMENT}

Clostridium tertium is abundant in soil, but is also found in animal and human intestines as well as in the commensal microbiome of the mouth cavity (Vanderhofstadt et al., 2010). It is a rare human pathogen. Reportedly, it was first described and its biochemical properties were studied in isolates from war wounds in the First World War (Ray et al., 2003). Therefore, C. tertium is considered capable of causing bacteraemia (Ray et al., 2003). In addition, it was found in persons with various ailments: meningitis, septic arthritis, enterocolitis, peritonitis, posttraumatic brain abscess, pneumonia, and necrotizing fasciitis and gangrene. C. tertium does not produce exotoxins and the mechanism of its virulence is not known (Ferrell and Tell, 2001; Ray et al., 2003; Vanderhofstadt et al., 2010). Moreover, its clinical importance is questionable since it is not entirely clear if it is a real pathogen or only a contaminant (Vanderhofstadt et al., 2010). It is supposed that $C$. tertium does damage to the gut mucosa when colonizing it (Ferrell and Tell, 2001), meaning it can penetrate into the bloodstream (Ray et al., 2003).

In veterinary medicine, $C$. tertium has been recognized as a causative agent of enteritis in cattle and pigs. AlMashat and Taylor in 1984 isolated similar 
bacteria from cattle with enteritis and phenotypically identified it as Sporolactobacillus species (Silvera et al., 2003). In artificially infected cattle, this bacterium caused mild diarrhoea. Ferrell and Tell (2001) reported an isolation of $C$. tertium from faeces of Trichoglossus moluccanus that vomited and had blood in faeces. It was assumed that contaminated water was the source of infection and that a diet rich in carbohydrates is a favourable medium for bacterial fermentation. Šeol et al. (2006) were the first to accuse C. tertium of causing abscesses, osteomyelitis and, finally, death in a dolphin, which was the first detection of this bacterium in marine animals.

Postollec et al. (2012) detected nine Clostridium species in various foodstuff, but not $C$. tertium (although they reviewed certain data during its previous detection). A long time ago, in 1965, Goudkov and Sharpe first published a paper on $C$. tertium detected in cheese and milk. They claimed that in spite of unfavourable conditions for $C$. tertium growth in dairy products, it can spoil certain cheese types. Later (Fernández et al., 2015), this bacterium was listed as one of the three clostridium foodborne pathogens in cheese, along with C. botulinum and C. perfringens. Le Bourhis et al. (2005) even developed and validated PCR primers for Clostridium spp. detection in cheese.

C. tertium was also detected in meat samples (Ersöz and Coşansu, 2018). Search for C. difficile with the API20A (System for the identification of anaerobes and with serological Clostridium Difficile Test Kit) resulted in C. tertium detection in one out of 101 samples of meat products (beef and chicken) collected from the market (Ersöz and Coşansu, 2018). The same agent was successfully recovered from foie gras and was proved to be capable of growing during storage at $8^{\circ} \mathrm{C}$ (Prevost et al., 2013). It was confirmed that C. tertium spores can be inactivated in meat by hydrostatic pressure and bacteriocins (Kalchayanand et al., 2003).

C. tertium is resistant to high temperatures, it can grow under various atmospheric conditions, can cause diarrhea and is present in both healthy and diseased humans (Silvera et al., 2003). Since it is considered an intestinal commensal in animals, it remains unclear whether animal feed should be regarded as a potential source of infection.

\section{ACKNOWLEDGEMENTS}

The authors are thankful for support granted by the Ministry of education, science and technological development of the Republic of Serbia for Scientific Projects No. TR 31071 and III 46002. 


\section{Authors' contributions}

DM completed the microbiological analyses of Soya semolina samples and isolated Clostridium tertium. MĐ identified C. pefringens using MALDI-TOF. DM, NA, MV prepared the manuscript, and NA did the reviewing, editing and supervision.

\section{Competing interest}

Authors declared no conflict of interests regarding the present paper.

\section{REFERENCES}

1. Collins, M.D., Lawson, P.A., Willems, A., Cordoba, J.J., Fernandez-Garayzabal, J., Garcia, P., Cai, J., Hippe, H., Farrow J.A. 1994. The phylogeny of the genus Clostridium: proposal of five new genera and eleven new species combinations. Int J Syst Bacteriol, 44(4), 812-26. doi: 10.1099/0020771344-4-812

2. ISO 7937:2010. Microbiology of food and animal feeding stuffs - Horizontal method for the enumeration of Clostridium perfringens - Colony-count technique.

3. Ersöz, Ş.Ş., Coşansu, S. 2018. Prevalence of Clostridium difficile isolated from beef and chicken meat products in Turkey. Korean Journal for Food Science of Animal Resources, 38, 759-767. doi: 10.5851/kosfa.2018.e14

4. Ferrell, S.T. and Tell, L. 2001. Clostridium tertium infection in a rainbow lorikeet (Trichoglossus haematodus haematodus) with enteritis. Journal of Avian Medicine and Surgery, 15(3), 204-208.

5. Fernández, M., Hudson, J.A., Korpela, R., de los Reyes-Gavilán, C.G. 2015. Impact on human health of microorganisms present in fermented dairy products: an overview. BioMed Research International, Article ID 412714. http://dx.doi.org/10.1155/2015/412714

6. Goudkov, A.V., Sharpe, M.E. 1965. Clostridia in Dairying. Journal of Applied Microbiology, 28(1), 63 - 73.

7. Kalchayanand, N., Dunne, C.P., Sikes, A., Ray, B. 2003. Inactivation of bacterial endospores by combined action of hydrostatic pressure and bacteriocins in roast beef. Journal of Food Safety, 23, 219-233. doi: 10.1111/ j.1745-4565.2003.tb00366.x

8. Le Bourhis, A.G., Saunier, K., Doré, J., Carlier, J.P., Chamba, J.F., Popoff, M.R., Tholozan, J.L. 2005. Development and validation of PCR primers to 
assess the diversity of Clostridium spp. in cheese by temporal temperature gradient gel electrophoresis. Applied and Environmental Microbiology, 71,29-38. doi:10.1128/AEM.71.1.29-38.2005

9. Postollec, F., Mathot, A.G., Bernard, M., Divanac'h, M.L., Pavan, S., Sohier, D. 2012. Tracking spore-forming bacteria in food: From natural biodiversity to selection by processes. International Journal of Food Microbiology, 158, 1-8. doi:10.1016/j.ijfoodmicro.2012.03.004

10. Prevost, S., Cayol, J.L., Zuber, F., Tholozan, J.L., Remize, F. 2013. Characterization of clostridial species and sulfite-reducing anaerobes isolated from foie gras with respect to microbial quality and safety. Food Control, 32, 222-227. doi : 10.1016/j.foodcont.2012.11.030

11. Regulation on the Quality of Animal Feed. 2010. Official Gazette of the Republic of Serbia, 4/10, p.71.

12. Ray, P., Das, A., Singh, K., Bhansali, A., Yadav, T.D. 2003. Clostridium tertium in necrotizing fasciitis and gangrene. Emerging Infectious Diseases, 9 (10), 1347 - 1348. doi: 10.3201/eid0910.030287

13. Silvera M., Finn B., Reynolds K. M., Taylor D. J. 2003. Clostridium tertium as a cause of enteritis in cattle. Veterinary Record 156: 60, 2003. doi:10.1136/vr.153.2.60

14. Šeol, B., Gomerčić, M.Đ., Naglić, T., Gomerčić T., Galov A., Gomerčić H. 2006. Isolation of Clostridium tertium from a striped dolphin (Stenella coeruleoalba) in the Adriatic Sea. Journal of Wildlife Diseases, 42(3), 709-711. doi:10.7589/0090-3558-42.3.709

15. Vanderhofstadt, M., Andre, M., Lonchay, C., Levecque, P., Holemans, X., Canon, J.L., D’Hondt, L. 2010. Clostridium tertium bacteremia: contamination or true pathogen? A report of two cases and a review of the literature. International Journal of Infectious Diseases, 14S, e335-e337. doi:10.1016/j.ijid.2010.03.004

Submitted: 06.08.2019. Accepted: 08.11.2019. 